\title{
Metody prowadzenia rozmowy \\ z politykiem doby PRL. \\ Wywiad biograficzny \\ i wywiad dziennikarski \\ na przykładzie spotkań \\ z Marianem Orzechowskim
}

\begin{abstract}
„Wielka to pokusa: sprawić, aby przemówili ludzie, którzy w różnych rolach współtworzyli nasz czas teraźniejszy. Większość z nas kryje w sercu przekonanie, iż owi ludzie posiadają klucz do poznania prawd nam niedostępnych; klucz do wydarzeń, do rządzących wydarzeniami mechanizmów; klucz do zrozumienia psychologicznych, mentalnych, ideologicznych uwarunkowań - i tych, co się ugięli, i tych co stawili opór. Nic, zdawałoby się, prostszego, niż wydrzeć im ten klucz. Domagać się, aby - jak przed sądem - złożyli świadectwo w nadziei, że tym samym odkryją się przed nami nowe pokłady wiedzy"2.
\end{abstract}

Krystyna Kersten

\section{Pamięć o komunizmie a wartość metody}

historii mówionej dla nauk historycznych

Przewidywalność, stabilność i niespieszność tworzą podstawę pamięci Polaków o czasach komunizmu, lecz dominującym wspomnieniem pozostaje ucisk

1 https://orcid.org/oooo-0oo2-0015-4523.

2 K. Kersten, Ktopoty ze świadkiem historii, [w:] T. Torańska, Oni, Warszawa 1990 (wyd. 2), s. 5. 
polityczny i społeczny władz Polskiej Rzeczypospolitej Ludowej. Dobre skojarzenia z minionymi czasami są oparte na małych przyjemnościach życia codziennego, z których można utkać nostalgię, lecz już trudniej oprzeć na nich jakieś ogólne przekonanie ${ }^{3}$. Starsze pokolenia, pamiętające PRL, wspominają ten okres historii Polski w jaśniejszych barwach niż pokolenia młodsze. Z tygla wspomnień wyłania się wypośrodkowany obraz, który powoli wypiera i zastępuje osobistą perspektywę przeszłości ${ }^{4}$. Pamięć zbiorowa o PRL jest na tyle zróżnicowana, że często staje się zarzewiem konfliktu, a stworzenie jednolitego obrazu o przeszłym systemie politycznym wydaje się nieosiągalne ${ }^{5}$.

Dominującym elementem peerelowskiej historiografii pozostaje historia konfliktu jako źródła dynamiki i przemian społecznych: konflikt między elitami politycznymi a elitami opozycyjnymi, między władzą a społeczeństwem oraz spór ideologiczny między komunistami i ich przeciwnikami ${ }^{6}$. Badania nad historią najnowszą są - o wiele bardziej niż inne dziedziny historii - podatne na społeczną presję, a sami badacze - często obarczeni pamięcią komunikacyjną o czasach, nad którymi się pochylają. Zadają więc źródłom historycznym, oparte na specyfice własnego pokolenia, pytania charakterystyczne dla ich profesji, ukierunkowane popularnością danej tematyki czy wynikające z nacisku politycznego?

Polscy historycy sięgali początkowo po metodę historii mówionej ze sporym dystansem, a większość z nich kierowała swoje zainteresowanie przede wszystkim ku przedstawicielom elit politycznych i społecznych, traktując przy tym ich relacje głównie jako materiał uzupełniający w badaniach historii politycznej epoki komunistycznej. Szersze wykorzystanie źródeł mówionych dotyczyło wyłącznie sytuacji, gdy wywiady ze świadkami historii były jedynymi dostępnymi źródłami informacji o przeszłości,

3 P.T. Kwiatkowski, Pamięć zbiorowa społeczeństwa polskiego w okresie transformacji, Warszawa 2008, s. 348.

$4 \quad$ J. Wawrzyniak, History and Memory: The Social Frames of Contemporary Polish Historiography, „Acta Poloniae Historica”, nr 103 (2011), s. 130.

5 Ibidem, s. 132; C. Robotycki, Pamięć o PRL-antropolog wobec doświadczenia przeszłości wtasnej kultury, „Konteksty. Polska Sztuka Ludowa”, t. 57 (2003), nr 3-4, s. 67.

J. Wawrzyniak, op. cit., s. 144.

Ibidem, s. 133-134. 
zwłaszcza w dobie PRL, kiedy korzystanie z archiwaliów była mocno ograniczone, a często wręcz niemożliwe ${ }^{8}$.

Obecnie obserwuje się odchodzenie badaczy historii mówionej od traktowania relacji jako źródła wiedzy o rzeczywistych wydarzeniach historycznych (faktach) na rzecz badania kultury pamięci, doświadczenia, indywidualnych i zbiorowych strategii budowania reprezentacji przeszłości oraz procesu nadawania jej znaczeń. Można zauważyć zwrot ku interpretacji tych źródeł jako tekstu kulturowego, co wymaga analizy strategii narracyjnych, systemu komunikacji i kulturowych wzorców pamiętania/wspominania. Historia mówiona, a właściwie dialog ze świadkami historii, daje możliwość przeżywania opowiadania, pozwala na budowanie tożsamości grupowej, edukację, rozwiązywanie konfliktów. Nurt obywatelsko-edukacyjny historii mówionej odegrał szczególną rolę w krajach komunistycznych Europy Środkowo-Wschodniej, kształtując - w opozycji do oficjalnej historiografii - wizję dziejów najnowszych oraz budowę postkomunistycznej pamięci zbiorowej. Dobrochna Kałwa wskazuje na taki antysystemowy i opozycyjny charakter historii mówionej, mającej moc destabilizacji oficjalnej historii i utartych sposobów myślenia o przeszłości. Relacje świadków historii pozostają często jedynym źródłem wiedzy o wydarzeniach historycznych, nieobecnych w głównym nurcie historii albo wypaczonych?

Eksploracja pamięci o komunizmie, a zwłaszcza jej (re)konstrukcja w warunkach traumatycznej zmiany, uwidacznia interdyscyplinarny charakter historii mówionej, ponieważ analiza relacji świadka historii w kontekście współczesnego dyskursu pamięci poszerza pole interpretacji skomplikowanego zjawiska pamięci zbiorowej o komunizmie ${ }^{10}$. Mimo że Kałwa nie traktuje wywiadów rekonstrukcyjnych jako istoty metody historii mówionej i uzupełnienia za jej pomocą wiedzy historycznej, to jednak wskazuje, że rozmowy z osobistościami ważnymi dla minionego okresu rzeczywiście pozwalają na analizę procesów decyzyjnych, wewnętrznych walk o władzę, działań skierowanych przeciwko opozycji i wielu innych kwestii nieodnotowanych w dokumentach, co wymaga uzupełnień i konfrontacji

8 D. Kałwa, 3R: Historia mówiona w polskich badaniach dziejów najnowszych, „Wrocławski Rocznik Historii Mówionej”, R. 7 (2017), s. 165-166.

9 D. Kałwa, Historia mówiona w krajach postkomunistycznych. Rekonesans, „Kultura i Historia", nr 18 (2010), http://biblioteka.teatrnn.pl/dlibra/Content/43596/Historia mowiona_www.kulturaihistoria.umcs.lublin.pdf (dostęp: 14 II 2019 r.). 
z relacjami uczestników wydarzeń. Interesującym i najbardziej obiecującym na tym polu kierunkiem jest, według Kałwy, nie rekonstrukcja wydarzeń historycznych, ale badania prozopograficzne. Wywiady są szczególnie przydatnym narzędziem, gdy celem badań staje się przedstawienie i analiza zbiorowego (auto)portretu środowiska lub pokolenia, dzięki którym odsłania się sfera motywacji, mentalności i doświadczeń. Do tego nurtu należą prace poświęcone elitom władzy komunistycznej Jerzego Eislera i Krzysztofa Dąbka, a kanonem metodologicznego warsztatu historyka jest podejście Krystyny Kersten, według której do interpretacji relacji świadka historii niezbędny jest warsztat interdyscyplinarny, łączący metody historyczne, psychologiczne i socjologiczne, przy jednoczesnym wprowadzeniu dodatkowej perspektywy analizy ilościowej ${ }^{11}$.

Przywołany wyżej Jerzy Eisler zwraca jednak uwagę, że wielu historyków, w tym także badaczy dziejów najnowszych, postrzega relacje historii mówionej jako źródło mało wiarygodne. Według niego historia mówiona spełnia cztery funkcje: 1) nieocenionego źródła informacji, gdy brakuje innych materiałów, 2) uzupełnienia, gdy badacz dąży do odtworzenia tła i zaplecza obyczajowo-towarzyskiego, 3) zbliżenia do prawdy historycznej dzięki zestawieniu wiedzy z dokumentów resortowych z wiadomościami pozyskanymi dzięki relacjom osób skrzywdzonych przez system komunistyczny oraz 4) zapisu wspomnień i wydarzeń widzianych z perspektywy środowisk opozycyjnych w systemach niedemokratycznych ${ }^{12}$. Pierwszą i drugą z tych ról mogą pełnić relacje przedstawicieli elit politycznych PRL. Komuniści nie publikowali swoich wspomnień, odnoszących się do własnej, minionej działalności politycznej i nie udzielali na ten temat wywiadów. Wydane autobiografie dotyczyły okresu przedwojennego, czasu wojny i okupacji, czasem kilku pierwszych powojennych lat, natomiast tzw. literatura rozrachunkowa, wydawana przez wyrzekających się dawnej „wiary” decydentów politycznych, niejednokrotnie przynosiła obraz nie mniej wypaczony niż literatura apologetyczna ${ }^{13}$. Choćby z tego powodu warto zbierać relacje polityków reprezentujących niegdyś Komitet Centralny Polskiej Zjednoczonej Partii Robotniczej (KC PZPR) i poddawać je dogłębnej analizie.

11 D. Kałwa, 3R: Historia mówiona..., s. 167-172.

12 J. Eisler, Refleksje nad wykorzystaniem relacji jako źródta $w$ badaniu historii PRL (Rozmowy z dysydentami i prominentami), „Polska 1944/45-1989. Studia i Materiały”, t. 6 (2003), s. 51-53.

13 [K. Kersten] J. Bujnowski, W oczach komunistów. Słowo wstępne, [w:] T. Torańska, Oni, Londyn 1985, s. 6. 
Sztandarowym przykładem rozmów z elitami politycznymi PRL są wywiady Teresy Torańskiej, opublikowane w książce Oni. Dziennikarka przeprowadziła je w latach 80 . XX w. z prominentami polskiej polityki lat 50. i 6o. XX w.: Edwardem Ochabem, Romanem Werflem, Stefanem Staszewskim, Wiktorem Kłosiewiczem, Leonem Chajną, Julią Minc i Jakubem Bermanem, reprezentując punkt widzenia opozycji oraz niezależną czwartą władzę. W tym celu sięgnęła po różne środki językowe oraz strategie komunikacyjne. Weszła jednocześnie w role prokuratora, historyka, dokumentalisty, dziennikarza i psychologa, aby uzyskać możliwie pełny obraz tożsamości swoich rozmówców, godząc warstwę historyczną opisywanych czasów z psychologiczną i starając się znaleźć odpowiedź na pytanie „jacy byli ci komuniści?". W celu ustalenia faktów stosowała metodę siedmiu złotych pytań, charakterystycznych dla przesłuchania: co się wydarzyło?, gdzie?, kiedy?, w jaki sposób?, dlaczego?, jakimi środkami? i kto?, uzyskując od rozmówców fakty, daty, nazwiska i liczby. Krótkie pytania ujawniały konflikt między prowadzącą wywiad, dążącą do wydobycia jak największej ilości informacji, a skłonnym do ukrycia pewnych szczegółów rozmówcą. Drugą stosowaną techniką było oskarżanie - dziennikarka jasno i wprost wyrażała przekonanie o winie rozmówcy. Trzecim sposobem było zaś prowokowanie, wymuszające określoną reakcję polityka ${ }^{14}$.

Podstawą ostatniego etapu rozmów Torańskiej był aspekt wartościujący. Przypominała komunistycznym dygnitarzom o ich odpowiedzialności za kraj i obywateli, wytykała lekceważenie społeczeństwa, oportunizm i obłudę, jako zachowania przyczyniające się do zaniku moralności. Rozmówcy Torańskiej, jak dziennikarka przyznała w rozmowie z Pawłem Reszką, chętnie odpowiadali na pytania, w przekonaniu, że ich odpowiedzi nigdy nie ujrzą światła dziennego i nie zostaną dopuszczone do publikacji przez cenzurę. Być może dlatego trwające po wiele godzin etyczne rozliczenia dające wgląd w system wartości polityków i ich wewnętrzny konflikt poglądów stały się w tamtym czasie w ogóle możliwe. Torańskiej udało się też odwrócić paradygmat kulturowy: nieprzywykli do przesłuchań polityczni prominenci znaleźli się pod ostrzałem prokuratorskich pytań, zarezerwowanych do tej pory dla reszty społeczeństwa, a nie dla reprezentantów władzy. Dziennikarka porzuciła zasadę dostosowania stylu do tematyki i posługiwała się językiem potocznym,

14 K. Rostkowska, Oni Teresy Torańskiej - między wywiadem a przestuchaniem, „Studia Medioznawcze", R. 59 (2014), nr 4, s. 129-134. 
słownictwem wartościującym i chwytami perswazyjnymi, demitologizując swoich rozmówców i prezentując obraz pozbawiony złudzeń oraz fałszu, wyraźny nawet w chwili, gdy zasłaniali się oni brakiem wiedzy ${ }^{15}$.

Dzięki technikom perswazji udało się Torańskiej uzyskać wgląd w mentalność komunistów oraz stworzyć profil psychologiczny Onych. Dziennikarka twierdziła, że poruszając najniższe ludzkie uczucia, wyzwalając w polityku próżność, strach i nienawiść, można od niego uzyskać prawie wszystko, przenikając przez fanatyczną wiarę w ideę, która z jednej strony zawężała pole widzenia, a z drugiej - pomagała w znalezieniu uzasadnienia dla najcięższych zbrodni. Otrzeźwienie polityków następowało dopiero na etapie zadawanych przez Torańską pytań prowokujących, którymi miała nie tylko ustalać fakty, lecz także skłaniać swoich rozmówców do refleksji ${ }^{16}$. Wartość wywiadów Torańskiej jako źródła na temat wydarzeń historycznych nie leży jednak w sferze faktograficznej. Przekaz jest bowiem zwodniczy i wymaga ogromnej dozy sceptycyzmu. Rozmowy pozwalają natomiast wniknąć w mentalność komunistów i uzupełnić historyczną układankę o informacje na temat mechanizmów funkcjonowania systemu komunistycznego $^{17}$. Pozostają wzorcowym zestawem technik zarówno dla historyków, jak i dla badaczy historii mówionej rejestrujących wywiady z politykami doby PRL, pomimo bardziej dziennikarskiego niż badawczego celu. Także w niniejszym artykule analiza wywiadów Torańskiej przeprowadzona przez Krystynę Kersten odgrywa rolę wzorca i materiału porównawczego z wywiadem biograficznym Mariana Orzechowskiego w pierwszej (część autobiograficzna) i w drugiej części relacji (etap stawiania pytań przez badacza), oraz podczas analizy przeprowadzonego z nim wywiadu dziennikarskiego.

\section{Sprawdzona opowieść}

Marian Orzechowski to absolwent Uniwersytetu Leningradzkiego, profesor historii Uniwersytetu Wrocławskiego, gdzie w latach 1972-1975 był rektorem i do 1981 r. wykładał. Podczas IX Zjazdu PZPR niespodziewanie trafił do najwyższego gremium partyjnego, a w październiku 1981 r. został jednym z dziewięciu sekretarzy KC, obejmując sektor ideologii. W czasie stanu wojennego organizował Patriotyczny Ruch Odrodzenia Narodowego,

\footnotetext{
$15 \quad$ Ibidem, s. 133-136.

16 Ibidem.

$17 \quad$ K. Kersten, Kłopoty ze świadkiem..., s. 6-7.
} 
natomiast w 1984 r. został rektorem partyjnej Akademii Nauk Społecznych. Rok później zastąpił na stanowisku ministra spraw zagranicznych Stefana Olszowskiego, nie mając doświadczenia dyplomatycznego ani mocnej pozycji politycznej ${ }^{18}$, ale ciesząc się poparciem najważniejszego decydenta politycznego w kraju - I sekretarza KC PZPR gen. Wojciecha Jaruzelskiego ${ }^{19}$.

Zainteresowanie naukowe fragmentem życiorysu Orzechowskiego, dotyczącym podróży dyplomatycznej do Iranu w 1987 r., skłoniło mnie do przeprowadzenia z nim wywiadu dziennikarskiego we wrześniu $2015 \mathrm{r}$. Podczas drugiego spotkania, w listopadzie 2018 r., zarejestrowałam z nim wywiad biograficzny, aby porównać oba źródła wywołane tymi dwiema metodami podczas rozmów z jednym z przedstawicieli elity politycznej PRL lat 80. XX w. Analiza porównawcza miała przynieść odpowiedź na pytanie, która z tych metod była bardziej skuteczna w poznaniu mentalności polityka, a jednocześnie za pomocą której metody łatwiej jest zanalizować przekaz na temat minionego systemu politycznego tworzonego przez ludzi zarządzających tym porządkiem politycznym. Przyjmując, że z analizy wspomnień świadka historii można wyciągać wnioski dotyczące pamięci społecznej zbiorowości, do której on należał ${ }^{20}$, obrałam za swój cel interpretację tego, „co” i „jak” jest przez Orzechowskiego pamiętane i opowiadane, oraz jak przywoływane zdarzenia są oceniane i jaki sens jest im nadawany.

Mentalność i system wartości Orzechowskiego ukształtowały się w komunistycznej Polsce, gdzie nie dbano, tak jak dzisiaj, o dokumentowanie i pielęgnowanie indywidualnej pamięci. W tamtym czasie raczej starano się wtłoczyć pamięć indywidualną w określone odgórnie przez władze ramy pamięci zbiorowej, w heroiczno-martyrologiczny schemat upamiętniania określonych wydarzeń i ich gotowych interpretacji ${ }^{21}$. Wydaje się, że w konsekwencji ideologicznego oddziaływania i wpajania przez lata pewnych schematów

18 Archiwum Akt Nowych (dalej: AAN), Telewizja Polska S.A., sygn. 1/2418, Noty biograficzne. Orzechowski Marian - przewodniczący Parlamentarnego Klubu Lewicy Demokratycznej, marzec 1990 r., s. 1; E. Maj, Relacja $z$ wizyty ministra spraw zagranicznych Mariana Orzechowskiego w Teheranie (2-6 luty 1987), „Przegląd Orientalistyczny", 2016, nr 1-2, s. 146.

19 AHM OPiP, sygn. AKC/23029, Relacja Mariana Orzechowskiego, 30 XI 2018 r. (sporządziła: Ewa Maj).

20 T. Maruszewski, Pamięć autobiograficzna, Gdańsk 2005, s. 10.

21 P. Filipkowski, Historia mówiona i wojna, Warszawa 2005, s. 10, http://biblioteka.teatrnn. pl/dlibra/Content/9618/Historia_mowiona_i_wojna.pdf (dostęp: 25 IV 2019 r.). 
myślenia, przekładających się na język, mówienie i pisanie o swojej historii w określony sposób może być stopione z tożsamością świadka historii tak mocno, że zmiana sposobu opowieści może być niemożliwa ${ }^{22}$. Reprezentanci ówczesnej nomenklatury politycznej, jako twórcy języka propagandy, z jednej strony wpadają we własne sidła nowomowy, która jednak z drugiej strony może być dla nich zaworem bezpieczeństwa, ułatwiającym pominięcie niewygodnych tematów i obronę przed dzisiejszą, oskarżającą ich interpretacją głęboko skrywanej przeszłości.

Pierwszą część wywiadu biograficznego z Marianem Orzechowskim, czyli swobodną opowieść o historii jego życia, niezakłóconą pytaniami badacza $^{23}$, cechuje schematyczność znamienna dla tzw. życiorysu mówionego. Świadek historii, przez ok. 40 minut, po kolei podawał swoje dane personalne, jak imię i nazwisko, datę i miejsce urodzenia, pochodzenie społeczne i adres zamieszkania, opowiedział o przebiegu edukacji, kwalifikacjach, etapach pracy, rodzinie, przynależności do organizacji społecznych, zainteresowaniach i perspektywach na przyszłość ${ }^{24}$. Posiłkując się początkowo bezpiecznym schematem życiorysu, świadek historii nie dał dostępu do spraw intymnych, dopiero w toku opowieści przechodząc do bardziej osobistych wspomnień.

Swobodne relacje biograficzne dają świadkowi historii więcej przestrzeni, niż ustrukturyzowany wywiad na podzielenie się epizodami z własnego życia, które są dla niego ważne i jednocześnie są tzw. sprawdzonymi opowieściami (successful stories). W takich opowieściach są obecne konwencje językowe, przekonania i oceny. W tych historiach odbija się stan świadomości mówiącego i kontekst kulturowy, w którym się porusza. Świadek historii odsłania tożsamość, ale też daje świadectwo swojej tożsamości ${ }^{25}$. Orzechowski wplótł w pierwszą, schematyczną, część wywiadu biograficznego, dwie epizodyczne historie z dzieciństwa. Połączył wspomnienie przyjazdu do Wrocławia ze zwięzłą opowieścią o spotkaniach z Niemcami, na początku

22 T. Maruszewski, op. cit., s. 17.

23 Por.: K. Kaźmierska, Wywiadnarracyjny-technika ipojęcia analityczne, [w:] Biografia a tożsamość narodowa, red. M. Czyżewski, A. Piotrowski, A. Rokuszewska-Pawełek, Łódź 1997, s. 35-36.

24 Por.: M. Rudnicka, Czy istnieje życiorys mówiony? O przenikaniu gatunków mówionych i pisanych - próba genologii na przykładzie analizy wypowiedzi autobiograficznych, „Wrocławski Rocznik Historii Mówionej”, R. 7 (2017), s. 76.

25 P. Filipkowski, op. cit., s. 6. 
i na końcu wojny, do których żywił ewidentną niechęć. Dobór słów i sposób przytaczania tych historii (Orzechowski w środku zdania wtrąca uwagę skierowaną do żony i płynnie wraca do jakby wyuczonej opowieści) wskazują, że możemy mieć do czynienia z takimi właśnie sprawdzonymi opowieściami. Jedną z nich jest fragment o niemieckim nalocie na miejscowość, w której się wychował:

Mieszkaliśmy pod lasem, pięknym lasem sosnowym, [...] był piękny słoneczny dzień. Cała rodzina wyległa, żeby się rozkoszować tym wrześniowym słońcem i nagle na niebie pojawiły się wysoko samoloty, i wszyscy, pamiętam jak dziś, zaczęli wołać: „O, angielskie! Angielskie!”. A te angielskie samoloty zniżyły się i zaczęły bombardować zakłady zbrojeniowe i wtedy okazało się, że to są samoloty nie angielskie, które przyleciały z pomocą [śmiech], tylko samoloty niemieckie ${ }^{26}$, które bombardowały [...]. I drugi epizod, z samego początku wojny, związany był z tym, że no mijały dni... Lucy ${ }^{27}$, bo nam przeszkadzasz... mijały dni, nie było chleba, nie było innych rzeczy i trzeba się wyprawić do miasta, do pierwszego sklepu, a było tak co najmniej kilometr, półtora od domu, w którym mieszkaliśmy, więc wyprawiono najmłodszego, czyli mnie. Ja miałem wtedy [...] osiem lat i szedłem, szedłem, szedłem, i nagle z daleka zobaczyłem dziwnego człowieka. Ten człowiek był w mundurze [...] był to mundur zupełnie inny [...] niż znany mi polski mundur [...] skojarzyłem, że to musi być Niemiec. Odwróciłem się i dosłownie [...] do domu przyleciałem krzycząc, że: „Niemcy, Niemcy, Niemcy!”.

W pamięci autobiograficznej przechowywane są głównie informacje dotyczące postawy świadka historii z przeszłości oraz zachowania ludzi napotkanych w ciągu jego życia. Poszczególne, jednostkowe działania, zsumowane, tworzą epizody, którym osoba nadaje własny sens. Wspomnienia zapisane w pamięci ewoluują jednak wraz ze zbieraniem nowych doświadczeń. Ex post świadek historii przypisuje epizodom inny sens w porównaniu z pierwotnym, co powoduje, że może z czasem odmiennie interpretować zachowania ludzi, a zwłaszcza osób, które go skrzywdziły ${ }^{28}$. Spotkania Orzechowskiego z Niemcami na początku wojny skłoniły go do złożenia następującej przysięgi: „[...] będę mścił się [...] na Niemcach, jeżeli tylko

\footnotetext{
26 Tu w oryginale przejęzyczenie: angielskie.

27 Mowa o Lucynie Orzechowskiej, żonie Mariana Orzechowskiego, która towarzyszyła rozmowie.

28 T. Maruszewski, op. cit., s. 19.
} 
przyjdzie okazja"29. Szansa - w jego mniemaniu - na spełnienie złożonej obietnicy nadarzyła się już w 1945 r., gdy mógł wskazać nowym władzom miejsce zamieszkania folksdojczów. Usprawiedliwia tamto swoje działanie krzywdami wyrządzonymi Polakom przez Niemców podczas wojny, ale także osobistymi przeżyciami z dzieciństwa jeszcze sprzed przyjazdu do Wrocławia. Przechodzi przy tym od razu do opowieści o doświadczeniach ze spotkań z Niemcami w pierwszych, tużpowojennych dniach, spędzonych w nowym mieście i o swoich zainteresowaniach naukowych:

No, pamiętam tych Niemców, którzy jeszcze mieszkali [...] na tej samej klatce schodowej, na Pułaskiego 23. Dzisiaj już w ogóle nie ma [...] tych domów, zostały zburzone i zostały tam wybudowane inne. Ale co zapamiętałem, że po pierwsze na samym dole mieszkał [...] krawiec, który szył mi pierwsze [...] ubranko. I nazywał się [...] Stedtke, ale jak zacząłem z nim rozmawiać, to okazało się, że on jest nie Niemiec, nie Polak, ale Ślązak, i że nazywa się Szczotka, [...] najzwyklejszy Szczotka, a Niemcy przerobili to na Stedtke i był Stedtke, więc to było spotkanie z tak zwanymi autochtonami, [o] których potem pierwsze publikacje moje i pierwsza praca doktorska powstała, i [...] pamiętam Niemców, którzy mieszkali nad nami, jeszcze na wyższym piętrze, i jak [...] wchodziłem ze szkoły [...] do mieszkania, i z góry schodziła starsza ode mnie dziewczyna niemiecka, to tak byli wyuczeni, że stawała pod murem, żebym ja mógł swobodnie przejść [...]. No widocznie [...] tak ich uczono, że mają przed [...] nowymi zdobywcami Wrocławia okazywać pełny [...] respekt ${ }^{30}$.

Opowieść o karierze naukowej Orzechowski połączył zaś klamrą z karierą polityczną, która, jak podkreślił, „[...] wtedy nie mogła być inna niż kariera, za przeproszeniem, partyjno-polityczna" ${ }^{31}$. W tej części nie zabrakło także elementów narracji opartych wyraźnie na wiedzy historycznej:

[...] w mojej pamięci, [...] w moim wyobrażeniu Wrocław pozostałjako najpiękniejsze miasto w Polsce. [...] nigdzie nie ma tyle pięknych parków, jak we Wrocławiu. Dwa wielkie parki.Południowy [...] i Wschodni Park, czyli za Mostem Grunwaldzkimi i...] w kierunku [...] obecnej Zajezdni ${ }^{32}$. [...] Były wspaniałe parki, których prawdopo-

29 Relacja Mariana Orzechowskiego.

so Ibidem.

31 Ibidem.

32 Świadek miał najprawdopodobniej na myśli Park Szczytnicki we Wrocławiu, za którym znajdowała się Zajezdnia Dąbie. 
dobnie nigdzie w Polsce [nie ma], być może w Szczecinie są podobne [...] parki. To był [...] pierwszy fenomen Wrocławia, który mi utkwił. A drugi, to był ten, że w mojej pamięci Wrocław pozostał, to też może zabrzmi dziwnie, jako najbardziej polskie z polskich miast. A dlaczego? Proszę wziąć pod uwagę, że [...] w żadnym mieście, na tak zwanych Ziemiach Odzyskanych, [...] nie skupiła się taka mieszanka Polaków [...] ze wszystkich stron, [...] całej Polski i byłej, i aktualnej, i [...] ze skupisk emigracyjnych, jak we Wrocławiu. Lwowiacy, Wilnianie, z Polski centralnej, czyli Królewiacy, ale także reemigranci z Francji, polscy reemigranci z Nadrenii i Westfalii, czyli [...] z Niemiec, Polacy wywiezieni na Syberię, Polacy wywiezieni do Kazachstanu. Miałem takich kolegów [...] w szkole, którzy przywieźli ze sobą swoje obyczaje, swoją mowę, i proszę zauważyć, w ciągu kilku, kilkunastu lat powstało społeczeństwo, które mówi, wedle mnie, najlepszym w Polsce językiem polskim. To jest prawdziwy Hochpolnisch, czyli język polski, język literacki. Nie ma mowy [...] czy gwary wrocławskiej, jest to czysta, polska mowa, jest to fenomen na skalę [...] polską i warto o [...] tym [...] wiedzieć $^{33}$.

W jego mówionym curriculum vitae, jak sam je nazwał, zabrakło jednak historii rodzinnych. O rodzicach Orzechowski wspomniał jedynie w kontekście politycznym, w ten sposób przemycając także opowieść o źródle swojego ideologicznego ukierunkowania:

No, we Wrocławiu zaczynała się moja kariera, kariera w szkole [w] trzecim gimnazjum... Najpierw w harcerstwie, a potem w ZMP, a właściwie nie w ZMP. Ponieważ moje tradycje rodzinne związane są z PPS-em, bo i mama, i ojciec, przed wojną, a mama po wojnie należała do PPS, to miałem sympatie PPS-owskie, i zapisałem się do organizacji, która się nazywała OM TUR, Organizacja Młodzieży Towarzystwa Uniwersytetów Robotniczych, która była filią, czy młodzieżową przybudówką PPS-u ${ }^{34}$.

Pierwsza część wywiadu biograficznego, przeprowadzonego z Orzechowskim, jest uporządkowana nie tylko pod względem elementów tworzących ogólne wrażenie sensu jego biografii, lecz także pod kątem chronologicznym. Informacje zarejestrowane w pamięci autobiograficznej są bowiem mocno uzależnione nie tylko od kontekstu, ale też porządkowane pod względem współrzędnych czasowo-przestrzennych. Czas jest również

\footnotetext{
33 Relacja Mariana Orzechowskiego.

34 Ibidem.
} 
obecny w reprezentacji epizodów w inny sposób: poszczególne zdarzenia, tworzące epizod, są uporządkowane z zachowaniem kolejności. Zasada uporządkowania w czasie pozwala pośrednio wnioskować, jakie zdarzenia w przeszłości mogły wpłynąć na inne zdarzenia. Brak uporządkowania lub też nagłe zmiany tego uporządkowania, mogą spowodować, że pewien ciąg zdarzeń straci dla świadka historii sens. Wydobywanie informacji z pamięci epizodycznej polega w znacznym stopniu na podróżowaniu w czasie i w przestrzeni, czyli na poszukiwaniu odpowiedzi na pytanie, co się zdarzyło, kiedy i gdzie. W pamięci autobiograficznej elementy epizodyczne dominują nad semantycznymi. Świadek historii pamięta swoją przeszłość jako ciąg zdarzeń, w których kiedyś uczestniczył i zapamiętuje te zdarzenia jako coś, co ma dla niego sens. Jeśli natomiast nie rozumie pewnego zdarzenia, stara się samodzielnie mu ten sens nadać. Błędne interpretacje zdarzeń mogą powodować zniekształcenia pamięci faktograficznej. Proces poszukiwania i nadawania sensu pamiętanym wydarzeniom jest jednym z najpoważniejszych źródeł zniekształceń pamięci autobiograficznej ${ }^{35}$.

W uporządkowanej pod względem czasowym i kolejności biografii Orzechowskiego wszystko zdaje się mieć sens, a raczej sens został tej narracji nadany przez świadka historii i tłumaczy zarówno jego wyniesione $\mathrm{z}$ domu polityczne ukierunkowanie, jak również zainteresowania badawcze, dla których inspiracją miało być spotkanie z wrocławskim autochtonem. Nie można jednak założyć, że narracja Orzechowskiego od początku do końca jest daleka od prawdy. Podał on gotową, sensowną interpretację swojego życia, w której jeden element pasuje i wynika z drugiego, tworząc ostatecznie zracjonalizowany obraz jego osobowości i historii życia. Orzechowski zmodyfikował swój mówiony życiorys tak, aby był ciekawszy, bardziej akceptowalny dla audytorium, a jego samego postawił w lepszym świetle. W efekcie prawdopodobnie odtworzył pierwotną pamięć, a rekonstruowane często w ten sam sposób opowieści dotyczące przeszłości zwykły ulegać licznym modyfikacjom ${ }^{36}$.

\section{Między prawdą a fałszem}

35 T. Maruszewski, op. cit., s. 19, 25-26, 33.

36 Ibidem, s. 35. 
Gdy w 1985 r. Marian Orzechowski objął stanowisko ministra spraw zagra-

nicznych, polska polityka zagraniczna wchodziła w okres wyraźnego odmrożenia ${ }^{37}$. Zmianę warty na stanowisku MSZ dostrzegł także ówczesny wicepremier Mieczysław F. Rakowski, dziennikarz, poseł, premier i ostatni I sekretarz KC PZPR, który w swoich dziennikach oceniał nowego ministra:

Facet od kilku lat robi zawrotną karierę. Widać, że jest dobrze widziany w Moskwie. Notabene, studia skończył w Leningradzie. Fakt nie bez znaczenia. Na ile go znam to facet o miernych zdolnościach, przeciętny. Rapackim nie będzie, ale - jak sądzę - nie o to chodzi. Chodzi o zmianę poglądu na ekipę, oczywiście nie tylko tu ${ }^{38}$.

Surowa ocena Orzechowskiego przez partyjnego kolegę mogła wynikać z przynależności obu polityków do różnych układów wewnątrz KC PZPR w II połowie lat 8o. XX w. Okres poprzedzający X Zjazd w 1986 r. był naznaczony napięciami między instytucjami reżimu i trawiącą partię walką o wpływy. Antoni Rajkiewicz, wówczas minister pracy w latach 1981-1982, opisał w 1984 r. zwalczające się układy polityczne tworzone przez pięć trójek. Podziały przybliżone przez Rajkiewicza były najprawdopodobniej odzwierciedleniem ówczesnej politycznej rzeczywistości i wskazywały na role odgrywane przez określone grupy, jak i wpływy poszczególnych osób. Jedną z przybliżonych przez niego trójek, współtworzoną przez gen. Wojciecha Jaruzelskiego, Floriana Siwickiego i Czesława Kiszczaka, miały otaczać cztery lobby. W dwóch z nich, na przeciwległych biegunach, znaleźli się Orzechowski i Rakowski. Orzechowski należał do grupy „profesorskiej”, zawdzięczającej swoją nazwę nie tylko wykształceniu, ale także charakterystycznemu dla profesorów postępowaniu i formułowaniu myśli, natomiast Rakowski współtworzył grupę „róg”, sięgającą w swoich działaniach po zagrywki propagandowe. Jeszcze inny podział wewnątrzpartyjny, układ „antyczyrkowski”39, stanowił kość niezgody między politykami. Wewnętrzna struktura polityczna zachowała swoje znaczenie aż do odejścia Orzechowskiego z Ministerstwa Spraw Zagranicznych w 1988 r. i reprezentowała pogląd silnej Moskwy, stawiającej na konfrontację z Zachodem, a nie odwilż w stosunkach międzynarodo-

37 A. Paczkowski, Dyplomacja polska czasów kryzysu, [w:] Historia dyplomacji polskiej. T. VI: 1944/1945-1989, red. W. Materski, W. Michowicz, Warszawa 2010, s. 855-863.

38 M.F. Rakowski, Dzienniki polityczne 1984-1986, Warszawa 2005, s. 321.

39 Józef Czyrek - działacz komunistyczny, minister spraw zagranicznych w latach 1980-1982 i członek Biura Politycznego w latach 1981-1989. 
wych, którą zapowiadał od 1985 r., a potwierdził zimą 1986 r., przywódca ZSRR Michaił Gorbaczow ${ }^{40}$.

Podobnie jak rozmówcy Torańskiej, Orzechowski nie oddał teki ministra $\mathrm{z}$ własnej woli ${ }^{41}$. Został od władzy odsunięty, o co miał mieć sporo żalu do I sekretarza KC PZPR, gen. Wojciecha Jaruzelskiego. Mimo to, jako były minister spraw zagranicznych, startował w wyborach czerwcowych w 1989 r., a do Sejmu dostał się w wyniku niepowodzenia listy krajowej ${ }^{42}$. Orzechowski kierował parlamentarnym klubem PZPR, a Rakowski pełnił funkcję I sekretarza KC PZPR z dala od ław sejmowych. Wzajemna niechęć ujawniła się także pod koniec 1989 r., kiedy Orzechowski postawił na zmiany stojące w opozycji do punktu widzenia Rakowskiego, tym samym podważając jego pozycję. Poparł też Tadeusza Fiszbacha, byłego sekretarza Komitetu Wojewódzkiego w Gdańsku, w zmaganiach z Rakowskim o liderowanie w partii po przegranych przez PZPR wyborach w 1989 r. Klub

40 Trójkę Jaruzelski-Siwicki-Kiszczak miały otaczać cztery lobby zwane „szałajdami” (Zbigniew Messner, Zbigniew Szałajda, Manfred Gorywoda), „manipulantami” (Mirosław Milewski, Józef Czyrek i Włodzimierz Mokrzyszczak) i właśnie "grupą profesorską", tworzoną - poza Marianem Orzechowskim - przez Henryka Bednarskiego i Tadeusza Porębskiego, oraz grupą „róg”, do której obok Mieczysława F. Rakowskiego należeli także Jerzy Urban i Wiesław Górnicki; zob.: P. Kowal, Koniec systemu władzy, Warszawa 2012, s. 46, 271-272; F. Musiał, Pierestrojka - droga do demokracji czy plan odwilży bis?, „Biuletyn IPN”, nr 5-6 (2009), s. 71.

41 Rozmówcy Torańskiej zostali wybrani spośród wąskiego kręgu elity czasów stalinowskich, ludzi, którzy w latach 1944-1956 zajmowali bardzo wysoką pozycję w partyjnej hierarchii, zostali jednak odrzuceni w toku politycznych zmagań przez swoich współtowarzyszy bądź też sami się odsunęli, będąc przedmiotem skierowanej przeciw nim kampanii, wpisanej w toczącą się walkę polityczną wewnątrz obozu władzy; K. Kersten, Ktopoty ze świadkiem..., s. 6, 7.

42 Chodzi o krajową listę wyborczą obejmującą trzydziestu pięciu kandydatów do Sejmu PRL X kadencji w 1989 r. Znaleźli się na niej przedstawiciele najwyższych władz państwowych i partyjnych związani z PZPR oraz ugrupowaniami satelickimi i kontrolowanymi przez partię organizacjami społecznymi. W wyniku wyborów 4 VI $1989 \mathrm{r}$. tylko dwóch kandydatów z tej listy uzyskało mandaty poselskie. W parlamencie zabrakło m.in. Mieczysława F. Rakowskiego, Aleksandra Kwaśniewskiego, Czesława Kiszczaka, Józefa Czyrka czy Floriana Siwickiego; P. Kowal, Koniec PZPR, „Polityka”, z 27 I 2015 r., https://www.polityka.pl/tygodnikpolityka/historia/1606819,2,koniec-pzpr.read, akapit: 4 (dostęp: 25 IV 2019 r.). 
w Sejmie prowadził swoją grę, niezależną od partyjnej centrali ${ }^{43}$. Konflikt, jaki trawił relację obu polityków, wydaje się więc bezsprzeczny. Jednak podczas wywiadu biograficznego, Orzechowski nie był skłonny opowiadać o sporach z Rakowskim:

[...] jak ja byłem w strukturach partyjnych, to on był w strukturach rządowych. [...] Jak on przyszedł na sekretarza po Jaruzelskim, to ja już też nie byłem [w strukturach partyjnych]. Więc z Rakowskim miałem, powiedziałbym, na stopie zupełnie neutralnej, przyjazne [stosunki], ale bez żadnych, bez żadnych... Być może, że temperamentami i mentalnością się troszkę [...] różniliśmy. [...] Nic bym nie mógł specjalnego powiedziećs ${ }^{44}$.

Zestawienie tak rozbieżnych opinii pokazuje, że Orzechowski niechętnie dzielił się kontrowersyjnymi fragmentami swojej historii. Istotą wywiadu biograficznego jest jednak nie tylko zebranie informacji, weryfikacja i dostarczenie nieznanych wcześniej faktów, ale także sama opowieść o zdarzeniach z przeszłości, dokonana przez świadka historii w pewnym procesie $^{45}$. Według Alessandra Portellego należy bowiem porzucić dyskurs rekonstrukcji wydarzeń na rzecz poszukiwania znaczeń. W przełożeniu na praktykę badawczą w zetknięciu ze świadkiem historii lepiej skupić się na interakcji, która doprowadzi nas do opowieści o doświadczeniu i zawartym w niej znaczeniu, zamiast skupiać się na chronologii wydarzeńn ${ }^{46}$. Interpretacja relacji świadka historii powinna odbywać się już na poziomie języka, którym przekazuje swoje życiowe doświadczenie ${ }^{47}$.

Podczas wywiadu dziennikarskiego w wypowiedziach Orzechowskiego nie brakowało sformułowań charakterystycznych dla języka propagandy. Orzechowski opowiadał np. o „solidarności [PRL] z siłami [...] antykolonialnymi, a ntyimperialistycznymi [...]”. Jednak sięgał po te określenia świadomie i z pewnym przekąsem, gdy, opisując relacje polsko-irańskie w latach

43 P. Kowal, Koniec PZPR, akapit: 9-11.

44 Relacja Mariana Orzechowskiego.

45 A. Stolarz, Historia mówiona $w$ warsztacie historyka mentalności, „Pamięć i Sprawiedliwość", nr 20 (2/2012), s. 106.

46 M. Kurkowska-Budzan, Informator, świadek historii, narrator - kilka wątków epistemologicznych i etycznych oral history, „Wrocławski Rocznik Historii Mówionej”, R. 1 (2011), s. 26.

47 P. Filipkowski, op. cit., s. 2. 
8o. XX w., stwierdził: „Jesteśmy z wami [Irańczykami] solidarni w walce $\mathrm{z}$ postkolonializmem, bo wtedy było bardzo modne słowo postkolonializm”, a gdzie indziej: „Postkolonialistami byli Amerykanie [...], którzy kolonii faktycznie [...] nie mieli" ${ }^{48}$.

W wywiadzie biograficznym Orzechowski podkreślał natomiast, że był (w przeszłości) pod wpływem propagandy, w ten sposób dystansując się od zarzutu, że wciąż mógłby być przesiąknięty komunistycznym przekazem i sposobem myślenia. Jednak słowa charakterystyczne dla propagandowej nowomowy jakby same cisnęły mu się na usta, gdy opowiadał o ówczesnej polityce. Sięgał przy tym po słowo „wtedy”, stawiając granicę między tym, co teraźniejsze, a tym, co przeszłe, jak we wspomnieniu o spotkaniu z Michaiłem Gorbaczowem:

I rozmowy dotyczące, [...] co nas szczególnie interesowało, miejsca i roli krajów demokracji ludowej we wspólnocie socjal[istycznej], bo to wtedy używano tego określenia, „wspólnota socjalistyczna”. Po raz pierwszy mówiliśmy o konieczności, żeby to były stosunki równoprawne i partnerskie ${ }^{49}$.

Podobnie, podczas opowieści o relacjach PRL z RFN, które miały być „[...] kluczem $w$ naszych stosunkach ze światem [...] zewnętrznym, ze światem [...] zachodnim, powiedzielibyśmy wtedy, kapitalistycznym. I to mi [Orzechowskiemu] utkwiło w głowie", pojawiły się wyrażenia charakterystyczne dla komunistycznej propagandy ${ }^{50}$. Dystans Orzechowskiego do przeszłości jest jednak pozorny i zdradza to - ponownie - język. Sięgając po zaimki, jak „my” i „nasze”, wyraźnie bierze odpowiedzialność za podejmowane decyzje i podkreśla ciągłą identyfikację z decydentami przeszłego systemu komunistycznego.

Orzechowski posługiwał się specyficznym językiem i własnym systemem kategorii, kodując w ten sposób ówczesną polityczną rzeczywistość ${ }^{51}$. Miał pełną świadomość realiów systemu politycznego, w jakim funkcjonował, i oddziałującej na niego propagandy komunistycznej, a także odgórnego przekazu o ZSRR, któremu uległ, wybierając się na studia do Rostowa nad

48 Wywiad z Marianem Orzechowskim przeprowadzony przez Ewę Maj, Wrocław, 17 IX 2015 r., zbiory prywatne Autorki.

49 Relacja Mariana Orzechowskiego.

50 Ibidem.

51 T. Maruszewski, op. cit., s. 45. 
Donem $^{52}$, „zanim skrystalizowały się [mu] poglądy”. Orzechowski otwarcie przyznał: „[...] byłem pod wpływem propagandy, chciałem zobaczyć [...] ten wielki, pierwszy kraj socjalizmu i zgłosiłem się na [...] wyjazd [do ZSRR], co oczywiście nie było przesądzone, bo trzeba było być zakwalifikowanym, [...] [i przejść] wybitnie ideologiczne i polityczne [szkolenie]”. Na miejscu miał jednak możliwość weryfikacji propagandy, którą karmiono wówczas Polaków. Orzechowski doskonale przy tym wiedział, że kwestionowanie takiego propagandowego przekazu było dla komunistów niedopuszczalne, dlatego milczał na temat radzieckiej rzeczywistości, gdy był już w Polsce:

[...] z różnych stron [...] mogłem [...] przysłuchiwać się z pewnego dystansu, temu, co pisano i co mówiono o Związku Radzieckim u nas, aczkolwiek się nie wypowiadałem, bo raczej było to niebezpieczne. Mnie na przykład zadziwiło, mimo wszystko, że Związek Radziecki, przodujący kraj socjalizmu, jest w sumie biedniejszy i [...] uboższy niż moja niesocjalistyczna Polska. Ale to była prawda. Poziom życia w Polsce był o wiele lepszy, nie mówię już o mieszkaniach... A że jeszcze na dodatek, na ostatnim roku studiów, ożeniłem się z Rosjanką, to poznałem także tak zwane komunalne mieszkania w Leningradzie [...], polegające na tym, że w korytarzu było dwanaście drzwi. Drzwi się otwierały do mieszkania, czyli [...] do jednego niewielkiego pokoju, gdzie była wspólna ubikacja i wspólna łazienka... [...]. Więc, jak słyszałem potem już te różne propagandowe historie o Związku Radzieckim, to milczałem, bo ja wiedziałem, jak to wygląda [...] naprawdę. Poznałem [...] życie moich kolegów ze wszystkich stron Związku Radzieckiego, z Ukrainy, z Białorusi, z Tatarstanu i z Azji Środkowej. [...] Poznałem także życie w Leningradzie, [...] mieszkanie mojej teściowej [...] i żony, i jej krewnych ${ }^{53}$.

Dopiero z czasem, już jako minister spraw zagranicznych, podczas podróży dyplomatycznej do ZSRR, polegając na zebranym doświadczeniu i zdobytej wiedzy, znalazł własny sposób zdefiniowania otaczającej go w Leningradzie rzeczywistości w bardzo szerokim kontekście:

[...] niby to była ta sama orientacja, ta sama partia, były troszeczkę inne [stosunki w świecie politycznym] i ja sobie potem znalazłem na to własne określenie, [...] kiedy już wgłębiłem się w różne zawiłości [...] historii naszej cywilizacji. Mianowicie,

52 Orzechowski pierwsze lata studiów w ZSRR spędził w Rostowie nad Donem, następnie wyjechał do Leningradu.

53 Relacja Mariana Orzechowskiego. 
to była kurtyna, za którą ukrywał się tak zwany bizantynizm [...]. To znaczy bardzo wyraźna hierarchia. Bardzo wyraźna podległość jednego szczebla hierarchii drugiemu szczeblowi, od dołu w górę, czy od góry w dół. Ze wszystkimi [...] akcesoriami tego bizantynizmu, na przykład łapówki, pochlebstwo, przekupstwo, korupcja. Wszystko to było i wszystko to się widziało. Niczego bez [...] wzjadki, jak Rosjanie mówią, nie dało się w tym systemie bizantyjskim [...] załatwić. U nas oczywiście też było sporo tego, ale tak, w takim stopniu i w takim [...] wymiarze, jak tam, nie widziałem. I dlatego na temat Związku Radzieckiego poza, powiedziałbym, przymusowymi sytuacjami, kiedy trzeba było powiedzieć [...] o wielkim Związku Radzieckim i o wiecznej przyjaźni, nie wypowiadałem się, bo był to dla mnie temat [...] bardzo niebezpieczny. Za dużo o tym [...] wiedziałem, za dużo widziałem po prostu. [...] Jedyny, u którego tego bizantynizmu nie widziałem, no ale to już były inne czasy, to był Michaił Gorbaczow ${ }^{54}$.

Orzechowski opowiadał zatem o swoim doświadczeniu z trzech poziomów: ucznia, który zachłyśnięty komunistyczną propagandą jedzie do ZSRR, później studenta, który poznaje realia i prawdopodobnie zaczyna rozumieć otaczającą go rzeczywistość, lecz mimo to po powrocie do Polski staje się częścią systemu PRL, wykładając podstawy marksizmu i leninizmu w Wyższej Szkole Rolniczej we Wrocławiu, a na koniec - głęboko zakotwiczonego we władzach państwowych partyjnego pracownika uczelni, a od 1981 r. członka najwyższego gremium partyjnego i jednego z dziewięciu sekretarzy KC, odpowiedzialnego za tę właśnie maskującą rzeczywistość ideologię, a następnie ministra spraw zagranicznych.

We wspomnieniach mogą zachodzić zmiany uwarunkowane nie tylko upływem czasu, lecz także tym, w jakiej relacji pozostają one z całym zbiorem wiedzy człowieka na temat siebie, innych ludzi oraz tworzonych z nimi związków ${ }^{55}$. Również rozmówcy Torańskiej - może nawet w większym stopniu niż Orzechowski - formułowali swoje myśli w języku propagandy, w którym mówili o ogólnych zagadnieniach, celach politycznych i ocenach sytuacji. Zawieszeni między dwoma porządkami ideologicznymi, systemami wartości i światami: światem rzeczywistym i światem przedstawień, każdy z własną logiką i sztucznym językiem, dokonywali mistyfikacji rze-

$\begin{array}{ll}{ }_{54} & \text { Ibidem. } \\ { }_{55} & \text { T. Maruszewski, op. cit., s. } 10 .\end{array}$ 
czywistości ${ }^{56}$. Język odsłania motywacje świadka historii. Szyfry, podteksty i wewnętrzne rozbieżności wynikają nie tylko z długoletnich nawyków posługiwania się językiem propagandy, lecz obnażają uwikłanie w sprzeczności, których sam opowiadający nie chce lub nie jest zdolny dostrzec. Komuniści kamuflowali je ideologiczną fasadą, czasem pokrywającą się z racją stanu, lecz nie byli w stanie samą narracją zmienić rzeczywistości. Pragnęli uznawać się za rzeczników polskiej racji stanu, łudząc siebie i innych, że nie było dla Polski innej drogi. Z tych prób wyłaniał się jednak intelektualny miszmasz ${ }^{57}$.

Lista zniekształceń rzeczywistości, które mają chronić ego świadka historii, jest bardzo długa ${ }^{58}$. Orzechowski podkreślał zepsucie ZSRR, objawiające się w „[...] sposobie wyrażania się i opinii prostych ludzi, którzy uważali, że na górze bez łapówki, bez prezentu, bez protekcji się nie da [...] załatwić”. Twierdził przy tym, że ten „ceremonializm” raził Polaków: „Myśmy to przyjmowali, ale bardzo oględnie. Nigdy nie było u nas takiego bizantynizmu jak tam" również szalała korupcja, lecz:

To naprawdę takie [...] życie mięsiste, to się odbywało na niższych szczeblach, bo do ministra, czy do sekretarza KC, to już te [...] drobne rzeczy, protekcje i jakieś inne skandaliki [...] nie dochodziły. To już było załatwiane na szczeblach niższych. Dochodziły tylko już spreparowane odpowiednio materiały do decyzji. To trzeba [...] mieć na uwadze ${ }^{60}$.

Orzechowski twierdząc, że elity polityczne nie brały bezpośredniego udziału w nieetycznym postępowaniu i przypisując je jedynie reprezentantom niższego szczebla władzy, nie tylko subtelnie usprawiedliwia decydentów, lecz także stara się zdjąć ze swojej grupy przynajmniej część odpowiedzialności. Tymczasem sam miał spotykać z całą masą takich propozycji, ale „podchodzić [do nich] bardzo niechętnie”, a ci, którzy próbowali skorzystać z jego protekcji, mieli się prędko zorientować, że nie był „podatny”. Jednak po chwili rozmowy przyznał, że sam skorzystał z protekcji znajomego

\footnotetext{
$56 \quad$ K. Kersten, Kłopoty ze świadkiem..., s. 12.

57 [K. Kersten] J. Bujnowski, W oczach komunistów..., s. 11-12.

58 T. Maruszewski, op. cit., s. 26.

59 Relacja Mariana Orzechowskiego.

60 Ibidem.
} 
z Departamentu Studiów Uniwersyteckich, który poparł go w inicjatywie stworzenia na Uniwersytecie Wrocławskim dwustu nowych etatów, gdy Orzechowski był rektorem: „Także widzi pani, protekcja - ostatnie uczucie ludzkie w drodze do piekła albo do nieba, jak kto woli"61.

W wywiadzie biograficznym Orzechowski starał się nie tylko obniżyć prestiż pełnionych przez siebie funkcji, lecz także deprecjonować znaczenie przysługujących mu, w związku z przynależnością do peerelowskiej elity politycznej, przywilejów: przydzielenia mieszkania, ułatwionego dostępu do dóbr materialnych czy wyjazdów za granicę. Stanowisko ministra spraw zagranicznych i rektora Uniwersytetu Wrocławskiego miało być „mozolną pracą biurową”, a „o życiu towarzyskim [na wyższym szczeblu władzy] mówić nie można". Poza przyjęciami czy koktajlami w ambasadach, według Orzechowskiego, elita polityczna PRL nie miała czasu na spotkania towarzyskie, a te które się odbywały, były zawsze podyktowane obowiązkami i pełnioną funkcją ${ }^{62}$. Przedstawiał siebie również jako liberała, namawiającego np. gen. Jaruzelskiego do wprowadzenia systemu demokratyczno-parlamentarnego i reformy partii komunistycznej, która miała przygotować grunt pod obrady Okrągłego Stołu. W tym wypadku, ale także w innych, budzących wątpliwość, a przypisywanych sobie postawach, poglądach i dokonaniach, Orzechowski zapewniał, że dowodem na jego prawdomówność są memoriały, które miał wysyłać do I sekretarza KC PZPR ${ }^{63}$ :

Idea była taka, [...] moja idea, żeby partia nie wtrącała się bezpośrednio do administracji. [...] Partia ma kierować [...], a nie rządzić [...]. Żadna decyzja na szczeblu administracyjnym, bez woli Partii nie została podjęta. [...] dowiadywałem się, że sekretarz Komitetu Gminnego to patrzy, czy wszystkie [...] pola zostały obsiane, czy buraki są we właściwym miejscu... Po cholerę to wszystko?! To nie jest [...] rola $\operatorname{partii}^{64}$.

61 Ibidem.

62 Por.: J. Szumski, Rozliczenia z ekipq Gierka 1980-1984, Warszawa 2018, s. 13-43.

63 Orzechowski w trakcie wywiadu podkreślał, że dzisiaj memoriały, na które się powoływał, znajdują się w warszawskim Archiwum Komitetu Centralnego PZPR, obecnie Archiwum Akt Nowych. Kwerenda archiwalna przeprowadzona w zespole KC PZPR z lat 1981-1989, dotycząca korespondencji gen. Jaruzelskiego z sekretarzami i członkami Biura Politycznego (sygn. XIA), nie potwierdziła słów Orzechowskiego.

64 Relacja Mariana Orzechowskiego. 
Politycznego i sekretarzom materiał informacyjny przygotowany w $1989 \mathrm{r}$. przez Józefa Werlego, dotyczący Polityczno-ekonomicznego uwarunkowania rozwoju Polski. W dokumencie sugerowano, że przełamanie społeczno-gospodarczego kryzysu byłoby możliwe dzięki „dokonaniu głębokich zmian ustrojowych polegających na przejściu od stalinowskich kanonów wojennego komunizmu do budowy nowego ustroju pokojowego, humanistycznego socjalizmu". Zrzucano w nim także, noszoną przez komunistów, propagandową maskę sprawczości partii:

Od 45 lat Polską rządzą komuniści [...] Prawdą jest, że mimo ogromnych zniszczeń wojennych, mimo obecnego kryzysu, dokonano tyle, że przeciętnemu Polakowi żyje się dziś o wiele lepiej, niż 50 lat temu. Jednakże wyciąganie z tego faktu propagandowych wniosków, że jest to wyłącznie zasługą partii, rządu i ustroju, że świadczy to dowodnie o wyborze jedynej słusznej drogi itp. jest oparte na zbyt jednostronnej i przez to niezbyt przekonywującej metodzie porównawczej. Np. w 1938 r. nie było w Polsce telewizorów, a teraz jest ich wiele milionów, ale trudno uznać to za sukces ustroju. Po prostu cały świat popędził naprzód i musimy wiedzieć, jakie miejsce w tym wyścigu zajmuje nasz kraj ${ }^{65}$.

Ponadto podkreślano $\mathrm{w}$ tym piśmie, że atmosfera głasnosti i pierestrojki była jedyną w swoim rodzaju szansą na „rzeczywiste pojednanie się narodu polskiego z narodami ZSRR”, a rządy Gorbaczowa miały, jak jeszcze nigdy wcześniej, dawać nadzieję na demokratyzację systemu. Bez wątpienia Orzechowski dbał o wzmocnienie ideologicznej sfery działalności partii w $1981 \mathrm{r}^{66}$, kontynuując

65 AAN, Wydział Propagandy, sygn. XXXVI-6o, J. Werlezpolecenia M. Orzechowskiego wysłano członkom BP, Z-com, Sekretarzom, Polityczno-ekonomiczne uwarunkowana rozwoju Polski, Warszawa, 13 I 1989 r., s. 1, 30-33.

66 Jeszcze zanim Orzechowski przejął stanowisko sekretarza do spraw ideologicznych, kierował przed IX Zjazdem KC PZPR do przewodniczącego Komisji Ideologicznej propozycje tematów, które powinny zostać przedyskutowane. Wśród propozycji Orzechowskiego, wówczas V przewodniczącego Komisji z Wrocławia, było zajęcie się kwestiami „o wyraźnie teoretycznym i ideologicznym charakterze, stanowiąc[ymi] przedmiot dyskusji i kontrowersji wewnątrzpartyjnych”, o „praktycznym, strategicznym, długofalowym znaczeniu” i „tematami o znaczeniu doraźnym”. Orzechowski sugerował także, aby efekty pracy Komisji znalazły odzwierciedlenie w praktyce, czyli w sposób „efektywny i kontrolowany” trafiły do Wydziału Pracy Ideowo-Wychowawczej KC oraz do komisji ideologicznych komitetów wojewódzkich, z którymi współpracę postrzegał 
zmagania o jej przetrwanie w 1989 r. pod skrzydłami Kremla, wyraźnie godząc się z odwilżą w stosunkach politycznych lub po prostu uznając, że nie ma już innego wyjścia ${ }^{67}$. Orzechowski połączył zatem w wywiadzie biograficznym apele kierowane do rządzących partią decydentów z przekonaniem o wpływie swoich interwencji na kształt dzisiejszego systemu politycznego w Polsce, który został ukuty w wyniku obrad Okrągłego Stołu.

Przytoczony fragment wywiadu biograficznego z Orzechowskim wpisuje się w spójną, charakterystyczną dla komunistów, narrację, w której frakcja partyjnych reformatorów i ich następców kreuje się na autorów demokratycznych przemian w Polsce po 1989 r. Jej esencją jest umacnianie przekonania, że to dzięki woli komunistycznych decydentów, którzy znaleźli przestrzeń dla działalności „Solidarności” w planach wprowadzenia niezbędnych w kraju zmian, doszło do wspólnego sukcesu, który zaczął się przy Okrągłym Stole. Orzechowski pomija kwestię upadającej polskiej gospodarki, stojącej pod znakiem zapytania przyszłości PZPR i rosnącej w siłę oraz w społeczne poparcie „Solidarności”, która przetrwała represje i stała się pod koniec lat 8o. XX w. realną siłą polityczną ${ }^{68}$.

Szczerość świadków historii zależy często od tego, ile czasu upłynęło od opowiadanego zdarzenia i czy ujawnienie szczegółów niesie dla opowiadającego jakieś konsekwencje. Dotyczy to zarówno faktów o charakterze politycznym, jak i społeczno-obyczajowym. Na skali wiarygodności najniżej plasują się jednak relacje wydarzeń politycznych i relacje tych świadków historii, którzy odgrywali w nich istotną rolę i nadal są czynni w organizacjach politycznych ${ }^{69}$. Należy mieć na uwadze, że w pamięci autobiograficznej obok faktów występują ich interpretacje i niezwykle często dochodzi

jako szczególnie ważną, „zwłaszcza w obecnej sytuacji wyraźnego ideowego zagubienia aktywu partyjnego i kompletnej dezorganizacji szkolenia partyjnego"; AAN, Wydział Ideologiczny KC PZPR, sygn. XXXV-56, Pismo Mariana Orzechowskiego do Stefana Olszowskiego, Wrocław, 15 IX 1981 r., s. 1-2.

${ }^{67}$ AAN, Wydział Propagandy, sygn. XXXVI-6o, J. Werle z polecenia M. Orzechowskiego wystano członkom BP, Z-com, Sekretarzom, Polityczno-ekonomiczne uwarunkowana rozwoju Polski, Warszawa, 13 I 1989 r., s. 1, 30-33.

68 To przekonanie Orzechowski wyraził m.in. w rozmowie z Pawłem Kowalem w 1999 r. Autorce nie udało się dotrzeć do nagrania, które nie znajduje się w zbiorach prywatnych badacza; zob.: M. Bernhard, J. Kubik, Roundtable Discord. The Contested Legacy of 1989 in Poland, [w:] Twenty Years After Communism. The Politics of Memory and Commemoration, red. M. Bernhard, J. Kubik, Oxford 2014, s. 77. 
do ich mylenia, co może mieć charakter obronny. Poprzez interpretacje bowiem świadek historii stara się nadać własnej biografii logiczny sens ${ }^{70}$.

Z życiorysu Orzechowskiego wyłania się także druga sfera jego aktywności. Jako doktorant, a potem pracownik naukowy Uniwersytetu Wrocławskiego, prezentował nieco odmienną postawę wobec porządku politycznego PRL. Widać to np. w powodach, dla których w latach 70. XX w. jego praca doktorska, poświęcona tzw. ludności autochtonicznej na Ziemiach Zachodnich i Północnych, nie została dopuszczona do druku:

[...] Wydawnictwo Ossolineum, mimo że zaprzyjaźniona była redakcja, musiało trzymać się [...] przepisów i skierowało pracę do cenzury. Bez pieczątki cenzury nie można było [...] nic publikować, a cenzura położyła veto! Bo jej się nie podobało to, co pisałem o tej weryfikacji właśnie. O tym, jak to [...] rzeczywiście przebiegało, a całą odpowiedzialność składałem zgodnie z prawdą na [...] administrację państwową, [...] na Polaków napływowych. I praca ta nigdy się nie ukazała ${ }^{71}$.

Jednak ani nieprzepuszczona przez cenzurę praca doktorska, ani też wyraźnie niezgodna z linią partii postawa Orzechowskiego podczas wydarzeń marcowych na Uniwersytecie Wrocławskim w 1968 r., nie stanęła mu na drodze do kariery politycznej:

I milicja nigdy nie wkroczyła. Aczkolwiek groźby były. Wzywano nas do Komitetu Wojewódzkiego [PZPR], do I sekretarza [Władysława] Piłatowskiego, który nam groził, że jeżeli strajku nie zakończymy, to milicja wkroczy. Potem wzywał mnie oddzielnie i tłumaczył mi, że ja nic nie rozumiem z tego: „Towarzyszu Orzechowski - mówi. - Wy nic nie rozumiecie, co się w tej Polsce dzieje”. Ja wysłuchałem, ale robiłem swoje ${ }^{72}$.

W chwili wprowadzenia stanu wojennego, 13 grudnia 1981 r., Orzechowski miał już ugruntowaną pozycję w KC PZPR. W wywiadzie biograficznym powiązał fakt wprowadzenia stanu wojennego ze swoją podróżą

\footnotetext{
70 [K. Kersten] J. Bujnowski, W oczach komunistów..., s. 7; T. Maruszewski, op. cit., s. 33.

71 Relacja Mariana Orzechowskiego.

72 Podczas wydarzeń marcowych Orzechowski spędził trzy dni w gmachu głównym Uniwersytetu Wrocławskiego razem ze strajkującymi studentami. Wraz z prof. Alfredem Jahnem, ówczesnym rektorem uczelni, „robiliśmy wszystko [...] żeby nie dać pretekstu do wkroczenia milicji na teren Uniwersytetu. [...] I milicja nigdy nie wkroczyła"; ibidem.
} 

w Moskwie w listopadzie 1981 r.:

Rozmawialiśmy w cztery oczy [...] dopytywał się: „Dlaczego wy zwlekacie [...] $\mathrm{z}$ rozprawieniem się z tą opozycją", z kontrrewolucją, jak to określano. I po raz pierwszy wtedy padła groźba, że: „Jeżeli wy tego nie zrobicie, to my będziemy musieli to zrobić". Mogę pani, nawiasem mówiąc, powiedzieć, że ta rozmowa przekazana Jaruzelskiemu w odpowiedni [...] sposób, przekonała go, że Rosjanie do Polski wkroczą. I to była między innymi, prageneza stanu wojennego. [...] rozmowa moja była w końcu listopada [...] 1981 r., a w grudniu został wprowadzony stan wojenny. To była taka ostatnia kropla, [...] że oni wejdą. A do tego nie można było dopuścić i stąd stan wojenny, który powiedziałbym, bez entuzjazmu, ale został [...] wprowadzony. Tak to wyglądało ${ }^{73}$.

Dopiero pytanie o reakcję gen. Jaruzelskiego na przywiezione wieści ujawniło, że teza o "pragenezie” stanu wojennego została ukuta przez samego Orzechowskiego i wynikała z podświadomej konstrukcji, uwidaczniającej się w domniemaniach i podejrzeniach czy też konkretnej potrzebie postrzegania i interpretacji przeszłości:

No zareagował, powiedziałbym, bardzo dramatycznie i ja myślę, że wtedy zapadło postanowienie, [...] że nie możemy dopuścić, żeby [...] Rosjanie nas wyprzedzili, wyręczyli, żeby okazali nam, powiedziałbym, przyjacielską usługę. No bo była dramatyczna decyzja. Ja sobie [...] z tego doskonale zdaję sprawę. Zwierzchnik Sił Zbrojnych, który musi podjąć decyzję, żeby podległe mu wojsko wyszło na ulice z czołga$\mathrm{mi}$, z bronią gotową do strzału, skierowaną przeciwko własnym współobywatelom. Podejrzewam, że nikt o [...] normalnym, powiedziałbym, stosunku do życia i o normalnych ludzkich uczuciach, [...] nie podejmuje takiej decyzji [...] ot tak, nonszalancko. To była chyba jedna z najbardziej dramatycznych decyzji w jego życiu. Zresztą wielokrotnie do tego [...] wracał, dawał do zrozumienia... Ja to [...] rozumiem ${ }^{74}$.

Wydaje się oczywiste, że pamięć ulega deformacji wraz z upływem czasu. Dzięki redukcji wewnętrznie sprzecznych treści świadek historii unika dysonansu poznawczego i tkwi w stworzonej przez siebie mitologii, niejedno-

\footnotetext{
73 Ibidem.

${ }^{74}$ Ibidem.
} 
krotnie i zarazem nieświadomie mówiąc nieprawdę. Podobnie rozmówcy Torańskiej starali się wytłumaczyć racje, jakimi kierowali się komuniści w Polsce, przedstawić uwikłania i mechanizmy prowadzonej polityki, sięgając po ideologię, ale częściej odwołując się do argumentów pragmatycznych. Efektem ich opowieści była własna wersja najnowszej historii Polski ${ }^{75}$. Według Krystyny Kersten wszyscy „oni” byli dalecy od powiedzenia choćby cząstki prawdy, a ich ogląd rzeczywistości został zdominowany przez ideologię i politykę ${ }^{76}$.

W przypadku wywiadów Torańskiej nie mamy jednak do czynienia z prostą opozycją: prawda - kłamstwo czy wiedza - niewiedza. Komuniści niby wiedzieli, ale tak jakby nie wiedzieli i odwrotnie - przyjmowali pewną wykładnię po części prawdziwą, i po części fałszywą, w głębi duszy kryjąc wątpliwości. Dopiero skonfrontowanie półprawdy z tym, co przemilczane, a następnie umieszczone we właściwym kontekście, może zbliżyć do poznania rzeczywistości. Niejednokrotne zasłanianie się niewiedzą i niedoinformowaniem przez świadków historii, jako nagminnie stosowany chwyt obronny, musi budzić nieufność ${ }^{77}$.

Analiza wywiadu biograficznego Orzechowskiego pokazuje, że choć reprezentuje on późniejsze pokolenie niż rozmówcy Torańskiej, to jego mentalność nie różni się zbytnio od wcześniejszych elit PRL. Można założyć, że zarówno Orzechowski, jak i Berman, Ochab, Staszewski, Kłosiewicz czy Werfel, wiedzieli dużo więcej, niż byli skłonni powiedzieć nawet najbardziej zaufanym osobom, ale także, że o wielu sprawach rzeczywiście nie wiedzieli. W tym wymiarze pytanie, czy wiedzieli, jak było naprawdę traci sens. Być może lepsze zrozumienie systemu, który ich ukształtował, pozwoliłoby odpowiedzieć na pytanie, w jakim stopniu chcieli powiedzieć prawdę o historii, którą współtworzyli i czy w ogóle leżało to w ich mocy. Należy bowiem rozróżnić, wyodrębnione przez Krystynę Kersten, poziomy: konkretnych, wyizolowanych faktów, rekonstrukcji rzeczywistego procesu historycznego i determinujących ten proces czynników, poziom oceny następstw sumy działań, składających się na historię. Według Kersten, Torańskiej nie udało się jednak nakreślić tych elementów, ponieważ

\footnotetext{
75 [K. Kersten] J. Bujnowski, Woczach komunistów..., s. 6.

76 Ibidem, s. 7.

$77 \quad$ K. Kersten, Kłopoty ze świadkiem..., s. 8.
} 
„pieczęć milczenia miała wciąż zakrywać usta nawet tych, którzy porzucili komunizm i kraj"78.

Na tendencyjność i jednostronność rozmówców Torańskiej wpłynął z pewnością fakt, że stali oni akurat pod pręgierzem nie tylko przeciwników, ale i partyjnych dygnitarzy ${ }^{79}$. Również Orzechowski, mimo że nie jest już czynnym politykiem, wciąż wydaje się stać na straży podejmowanych przez rząd PRL decyzji, jak też dbać o pamięć o ludziach, wraz z którymi te zarządzenia wprowadzał w życie. Podobnie do rozmówców Torańskiej, pozostał więc w tym sensie wierny komunistycznym poglądom i nie odżegnywał się od swojej politycznej przeszłości, trwając w przekonaniu o słuszności sprawy, o którą walczył, i z którą nadal się identyfikuje, nawet w tak kontrowersyjnej kwestii, jak wprowadzenie stanu wojennego ${ }^{80}$.

Torańskiej udało się jednak odsłonić wiele stron nieoficjalnego życia elity komunistycznej. Wykorzystując chwilę nieuwagi i nieświadomość rozmówców, dziennikarka zdobyła opowieści o relacjach, powiązaniach oraz układach politycznych i towarzyskich ${ }^{81}$. Tymczasem Orzechowski w wywiadzie biograficznym zdawkowo odpowiadał na pytania dotyczące sfery towarzyskiej i niechętnie opisywał życie rodzinne. Zachował pełną świadomość i kontrolę nad przekazywanymi informacjami na temat siebie i swojej postawy w kontrowersyjnych, pod względem politycznym, wydarzeniach, podając ich gotową i uzgodnioną wśród obrońców komunizmu interpretację.

\section{Wywiad dziennikarski}

Ostrożność, przebiegłość, dobre przygotowanie do spotkania i wyszkolenie w odpowiadaniu na dziennikarskie pytania, powodują, że politycy są oceniani przez dziennikarzy jako szczególnie wymagający i trudni rozmówcy. Nierzadko podejrzewani o kłamstwo, rzeczywiście niejednokrotnie mówią nieprawdę, lecz, według brytyjskiego dziennikarza Harolda Fraymana, nie częściej niż większość ludzi: „Politycy nie są z natury bardziej skłonni do nieuczciwych zachowań, ale zdarza im się podawać za fakt coś, co mają nadzieję, że rzeczywiście się wydarzy”. W wywiadach często mówią więc półprawdę i kładą nacisk na fragmenty, na których zależy im najbardziej,

78 Ibidem.

79 [K. Kersten] J. Bujnowski, W oczach komunistów..., s. 23.

$80 \quad$ Ibidem, s. 6; K. Kersten, Ktopoty ze świadkiem..., s. 7.

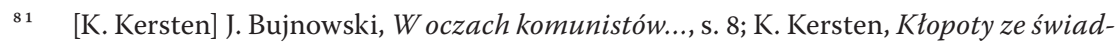
kiem..., s. 9 . 
aby dotarły do szerszej publiczności. „Politycy mogą się dzielić na prawicowych i lewicowych, nieustępliwych, ideologizujących lub pragmatycznych, ale pytanie, które wszyscy z nich zadają sobie podczas wywiadu, jest zawsze takie samo: "Jak moje słowa wypadną w druku?»"82.

Podczas wywiadu dziennikarskiego z Marianem Orzechowskim nie rozmawialiśmy o bieżącej polityce, a on sam nie był już czynnym politykiem. W centrum mojego zainteresowania leżało konkretne zdarzenie z jego życia - pozbawiona kontrowersji politycznych wizyta dyplomatyczna w Teheranie w 1987 r. i poszerzenie wiedzy, płynącej z archiwaliów, na temat stosunków polsko-irańskich. Dla historyka relacja świadka historii jest często kolejną odsłoną wydarzeń lub ich fragmentów ze zdefiniowanej wcześniej przez badaczy puli faktów historycznych ${ }^{83}$. Orzechowski jednak kilkukrotnie przyznawał, że pewnych kwestii „nie pamięta” lub o nich „nie słyszał”, jak np. stanowiska władz PRL, zgodnie z którym przedłużenie się irańsko-irackiego konfliktu z lat 1980-1988, miało przyczynić się do zaangażowania Stanów Zjednoczonych na Bliskim Wschodzie:

Tak, [...] ja sobie nie przypominam [...] żebym takiego argumentu używał. Aczkolwiek z dzisiejszej perspektywy mogę sobie wyobrazić, że wtedy można było na przykład zachęcać, [...] i jedną, i drugą stronę, żeby możliwie szybko ten konflikt zakończyli, bo to jest tylko na rękę imperialistom, czyli Ameryce. [...] Więc taka ideologia, jak najbardziej ${ }^{84}$.

Dopiero na etapie dyskusji i wymiany poglądów, stymulacji pamięci, sięgnięcia po notatki, Orzechowski przypominał sobie istotne fragmenty dotyczące relacji polsko-irańskich, a także umieszczał je w kontekście polskiej polityki zagranicznej. Również stawiane przeze mnie tezy zadecydowały o charakterze wywiadu. Orzechowski weryfikował podawane informacje, stając do nich w kontrze, nie pamiętając pewnych wydarzeń lub dopowiadając swoją historię, a w konsekwencji dzieląc się myślami, które z dużym prawdopodobieństwem nie pojawiłyby się $\mathrm{w}$ trakcie swobodnej narracji ${ }^{85}$.

82 S. Adams, W. Hicks, Wywiad dziennikarski, Kraków 2007, s. 129-130, 133.

83 P. Wrona, Żywe źródło historyczne. Historia mówiona oczami historyka, [w:] Historia mówiona $w$ świetle nauk humanistycznych i społecznych, red. S. Niebrzegowska-Bartmińska, J. Szadura, M. Szumiło, Lublin 2014, s. 257.

84 Wywiad z Marianem Orzechowskim.

85 Ibidem. 
134 Zdecydowanie żywsze były natomiast jego wspomnienia o Teheranie, niezrealizowanej wycieczce do Persepolis czy o koleżance z gimnazjum nr III we Wrocławiu, która wróciła z Iranu do Polski przez Wielką Brytanię:

No mnie to bardzo interesowało, powiedziałbym, z takich osobistych względów. Bo w gimnazjum we Wrocławiu, w trzecim gimnazjum, miałem w klasie koleżankę, która była dzieckiem... [...] przez Iran na Zachód wędrowała i przez Syrię, Brytanię wróciła do Polski, więc ona mi trochę o tym Teheranie opowiadała ${ }^{86}$.

Wywiady tematyczne, dziennikarskie mogą mieć zatem także charakter biograficzny, w którym rozmówcy (re)konstruują swoją biografię i ujmują wątki szczególnie ważne zarówno dla badaczy, jak i dla rozmówców ${ }^{87}$.

Brak politycznych kontrowersji wokół wizyty w Teheranie i pozbawione antagonizmów stosunki polsko-irańskie, wykluczające osobiste zaangażowanie i troskę o wizerunek rozmówcy, pozwalają sądzić, że wywiad dziennikarski z Orzechowskim może służyć do nakreślenia, wyłuszczonych przez Kersten, elementów składających się na historię, czyli rzeczywistej rekonstrukcji procesu historycznego, oceny następstw sumy działań i wyizolowania konkretnych faktów ${ }^{88}$. Należy mieć jednak na uwadze, że rozmówcy, dzieląc się swoimi wspomnieniami, a przy tym opiniami, nie relacjonują bezpośrednio wydarzeń, nie odtwarzają ich, lecz wyrażają przez nie: co myślą, że wiedzą; co myślą, że widzieli i co myślą, że przeżyli ${ }^{89}$.

\section{Jak rozmawiać z politykiem doby PRL?}

\section{Wywiad biograficzny a wywiad dziennikarski na tle innych metod}

Według publicysty Piotra Wojciechowskiego każdy, kto zahaczył o „hybrydalną międzyepokę" PRL, jest skazany na rozpamiętywanie zarówno jej krzywd, jak i łatwych słodyczy, ale zarazem będzie odrzucał oceny historyków i polityków, ponieważ „każdy z nas wie lepiej, jak było”. Relacje komunistów, mocno osadzonych w peerelowskim systemie politycznym i broniących swoich racji oraz decyzji z przeszłości, stoją często w kontrze

\footnotetext{
86 Ibidem.

87 P. Filipkowski, op. cit., s. 5.

$88 \quad$ K. Kersten, Kłopoty ze świadkiem..., s. 8.

89 A. Portelli, nierejestrowana wypowiedź podczas Oral History Association Annual Meeting, Pitsburgh, USA, 2008, za: M. Kurkowska-Budzan, op. cit., s. 27. 
do narracji osób reprezentujących opozycję polityczną. Obie perspektywy historii PRL przyczyniają się jednak do budowy, niejednorodnej w swojej naturze, postkomunistycznej pamięci zbiorowej. Różniące się wizje niewątpliwie wzbogacają obraz czasów komunistycznych, choć zarazem są odzwierciedleniem konfliktu toczącego najnowszą historię Polski.

Trudno jest jednak zestawić wartość relacji opozycjonisty, świadka historii, którego głos był przez lata zagłuszany, ignorowany i represjonowany przez władze PRL, ze stojącym po drugiej stronie politycznej barykady członkiem elity PRL. Nie można zarazem uznać, że historia, którą przekazuje badaczowi komunista, jest niewarta uwagi. Każda opowieść o życiu powinna zostać wysłuchana, lecz ze świadomością różnicy w procesie rejestrowania wywiadu i jego późniejszej analizy. Poznanie faktycznego stanowiska i odkrycie mentalności polityka, jak wykazałam, jest utrudnione pod wieloma względami. Świadoma ochrona własnego wizerunku czasem wręcz uniemożliwia osiągnięcie założonego celu, przyczyniając się do powstania intelektualnego miszmaszu, relacji schematycznej, zinterpretowanej opowieści, opartej na półprawdach, która nie gwarantuje faktograficznej jakości wywiadu i zamyka dostęp do mentalności polityka, choć poznanie tych maskujących mechanizmów też powie wiele o jego mentalności. Kluczem do poznania tak chronionej tożsamości, może być jednak podjęcie próby zdobycia zaufania rozmówcy. Według amerykańskiego historyka Donalda A. Ritchiego, uprzedzenie polityka, jeszcze przed włączeniem dyktafonu, o celu nagrania, jakim jest utrwalenie jego wspomnień dla przyszłych pokoleń, a także stworzenie materiału do badań naukowych, powinno zagwarantować szczerość i otwartość świadka historii, skutkującą opowiedzeniem swojej historii, bez obawy o wizerunek ${ }^{91}$. Na przeszkodzie może jednak stanąć wpojony politykowi schemat odpowiedzi, silniejszy od świadomości samego świadka historii, reprezentującego elitę komunistyczną doby PRL, ostatecznie decydujący o powierzchowności wywiadu.

Podczas wywiadu dziennikarskiego Orzechowski pełnił w większym stopniu rolę historyka i profesora niż polityka, a wyuczone, dyplomatyczne uniki i polityczne nawyki, ujawniły się w większym stopniu w trakcie wywiadu biograficznego niż w rozmowie poświęconej jego wizycie w Teheranie. Orzechowski zachował pełną świadomość przekazywanych treści, natomiast podczas wywiadu dziennikarskiego swobodniej odpowiadał na pytania, które nie dotyczyły jego

91 D.A. Ritchie, Doing Oral History. A Practical Guide, Oxford 2003, s. 101-102. 
życiorysu, peerelowskiej polityki zagranicznej i pełnionych funkcji. Konfrontacja dwóch metod rozmowy z tym samym przedstawicielem elity politycznej PRL, zastosowanych przez tę samą osobę w niedużym odstępie czasu, pokazała, że podczas wywiadu biograficznego Orzechowski poddał swoją opowieść autocenzurze, zarówno w pierwszej, swobodnej części rozmowy, jak i - w pewnej mierze - w drugiej części, w której odpowiadał na pytania. Jednocześnie wywiad dziennikarski, oparty na pytaniach perswazyjnych, którego tematem przewodnim nie były kontrowersyjne kwestie polityczne, grożące ukazaniem świadka historii i ludzi, z którymi podejmował dyskusyjne decyzje w przeszłości, w złym świetle, pozwala na ustalenie pewnych faktów historycznych. Wydaje się, że neutralny wywiad tematyczny, nieukierunkowany chęcią „upamiętnienia siebie”, jest bardziej wartościowy pod względem faktograficznym $w$ rozmowach $\mathrm{z}$ elitami politycznymi.

Rozmowy z politykami muszą jednak budzić nieufność badacza zarówno w chwili wywiadu, jak i późniejszej analizy. Irlandzki dziennikarz, Conor McGrath, proponuje, aby w rozmowach z przywykłymi do udzielania wywiadów elitami politycznymi, mającymi świadomość oddziaływania na audytorium za pomocą przekazywanych informacji, pozwolić na swobodną wymianę myśli i dyskusję. McGrath, przeprowadzając wywiady z lobbystami, odkrył, że metoda dyskusji przyniosła lepsze wyniki, niż wywiad oparty na zadawaniu pytań i krótkich odpowiedziach. Swobodna dyskusja angażująca badacza i świadka historii, z której obaj rozmówcy czerpią satysfakcję i wymieniają się informacjami, forma pośrednia między wywiadem ustrukturyzowanym a nieustrukturyzowanym, pozwala zbudować najbardziej efektywny i owocny dialog. Pewna doza wytrwałości badacza gwarantuje natomiast, że wywiad obejmie wszystkie tematy, jakie polityk zamierzał podjąć, a elastyczność umożliwi świadkowi historii odpowiedzenie na pytania w indywidualny sposób, nakierowując - również badacza - na wcześniej nieprzewidziane wątki. Swobodna dyskusja może być zatem kluczem do posiadanej przez polityków wiedzy w nieco większym stopniu, niż wywierana na świadkach historii presja, ponieważ uzyskane tym sposobem informacje, opierające się na wymuszonych odpowiedziach, są raczej pozbawione wartości naukowej. Badacz powinien oddać świadkowi historii głos, zamiast sterować rozmową, pozwalając mu decydować o tempie wywiadu i informacjach, jakich zdecyduje się udzielić ${ }^{92}$.

92 C. McGrath, Oral history and political elites. Interviewing (and transcribing) lobbyists, [w:] Oral History. The challenges of dialogue, red. M. Kurkowska-Budzan, K. Zamorski, Amsterdam-Philadelphia 2009, s. 49-50, 58. 
Należy mieć jednak na uwadze, że pamięć autobiograficzna ma głównie charakter osobisty, więc trudno zweryfikować, czy wszystkie informacje na temat przeszłości świadka historii są prawdziwe ${ }^{93}$. Lecz wszędzie tam, gdzie naprawdę byłoby się czego wstydzić, świadek historii zazwyczaj zasłania się brakiem pamięci, a nieporównanie bardziej jest wiarygodny dla badacza, gdy potrafi mówić źle o sobie samym i swoich wcześniejszych dokonaniach oraz wypowiada sądy niepopularne z dzisiejszego punktu widzenia94. Posiada pewien system poglądów, które można określić mianem potocznej teorii świata i może tak modyfikować materiał pamięciowy i wypełniać luki treściami zgodnymi z własnymi teoriami, aż dochodzi do służących jego wizerunkowi zniekształceń, pozwalających na utrzymanie pozytywnego przekonania o samym sobie. W pamięci autobiograficznej znajdują się bowiem wyselekcjonowane informacje, które sprzyjają pielęgnowaniu wspomnień o dużej wadze i decydują o wysokim poczuciu własnej wartości, tożsamości i samoocenie ${ }^{95}$. Dopiero konfrontacja półprawdy z tym, co przemilczane, a następnie umieszczone we właściwym kontekście, jak twierdziła Krystyna Kersten, może zbliżyć do poznania rzeczywistości ${ }^{96}$.

\section{Podsumowanie}

Wykorzystywanym przeze mnie metodom wywiadu biograficznego i wywiadu dziennikarskiego towarzyszyła naturalna zmiana roli z prowadzącej z rozmówcą dialog dziennikarki-badaczki, traktującej wywiad jako źródło wiedzy uzupełniającej posiadane informacje, ale zarazem otwierające nowe wątki, na badaczkę historii mówionej, sięgającą po metodę biograficzną, której celem jest odkrycie tożsamości polityka doby PRL. Wywiad dziennikarski przeprowadzony z Orzechowskim rzeczywiście pozwolił na poszerzenie wiedzy o konkretnym zdarzeniu z przeszłości. Tymczasem wywiad biograficzny umożliwił uzyskanie obrazu mentalności i tożsamości polityka. Według historyka Karola Modzelewskiego, „jak ktoś brał w czymś udział osobiście, zapamiętał to w sposób, który był potrzebny dla jego aktywności" ${ }^{\text {97 }}$. Komuniści przekazują zatem swoją

\footnotetext{
93 T. Maruszewski, op. cit., s. 38.

94 J. Eisler, op. cit., s. 60.

95 T. Maruszewski, op. cit., s. 26, 36-37.

$96 \quad$ K. Kersten, Ktopoty ze świadkiem..., s. 8.

97 Modzelewski - Werblan. Polska Ludowa, oprac. R. Walenciak, Warszawa 2017, S. 9-10.
} 
prawdę, swój obraz rzeczywistości, interpretacje i osądy, a szansa na rekonstrukcję rzeczywistości, na podstawie ich relacji, była i jest ograniczona przez miejsce, jakie zajmowali i nadal zajmują w polskim społeczeństwie ${ }^{98}$. Rozmowy z komunistami dają jednak wgląd w ich mentalność, dokumentują formację ideologiczną i umysłową, która należy już do przeszłości. Odczytywane w ten sposób na pewno mogą pomóc w zrozumieniu złożonych procesów polskiej historii ${ }^{99}$.

Analiza wywiadu biograficznego i dziennikarskiego dała szansę na dotknięcie mentalności Orzechowskiego jako naukowca i polityka, a odpowiedzi (lub ich unikanie) na zadawane pytania odsłaniały nowe aspekty jego sposobu patrzenia na przeszłość z dzisiejszej perspektywy, lecz nie mentalité czasów samych wydarzeń, w których brał udział czy też których był obserwatorem. Informacje dotyczące przeszłych zdarzeń ulegają licznym modyfikacjom w wyniku wielokrotnego odtwarzania wspomnień. Opowiadając historię swojego życia, Orzechowski mógł ją modyfikować tak, aby była ciekawsza, bardziej akceptowalna przez audytorium, a jego samego przedstawiała w lepszym świetle, podając w wątpliwość faktograficzną wartość jego opowieści. Ostatecznie mógł odtworzyć poprzednio opowiedzianą historię, a nie zdarzenia pierwotne. W Orzechowskim mieszały się role naukowca i polityka, lecz ostatecznie wygrał raczej pragmatyzm osoby dbającej o wizerunek swój i kolegów-polityków. Trudno jednoznacznie osądzić, czy była to prawda czy fałsz. Pewne jest natomiast, że nie ma fałszywych świadectw mówionych - wszystkie są psychologicznie prawdziwe, a ich prawda może być równie istotna, jak faktograficznie wiarygodne źródło ${ }^{100}$.

\footnotetext{
98 K. Kersten, Ktopoty ze świadkiem..., s. 8-9.

99 Ibidem, s. 13.

100 P. Filipkowski, op. cit., s. 5-6.
} 
Adams S., Hicks W., Wywiad dziennikarski, Kraków 2007.

Bernhard M., Kubik J., Roundtable Discord. The Contested Legacy of 1989 in Poland, [w:] Twenty Years After Communism. The Politics of Memory and Commemoration, red. M. Bernhard, J. Kubik, Oxford 2014, s. 60-84.

Eisler J., Refleksje nad wykorzystaniem relacji jako źródta w badaniu historii PRL (Rozmowy $z$ dysydentami i prominentami), „Polska 1944/45-1989. Studia i Materiały”, t. 6 (2003), s. 49-64.

Filipkowski P., Historia mówiona $i$ wojna, Warszawa 2005, s. 1-13, http://biblioteka.teatrnn.pl/ dlibra/Content/9618/Historia_mowiona_i_wojna.pdf (dostęp: 25 IV 2019).

Kałwa D., Historia mówiona w krajach postkomunistycznych. Rekonesans, „Kultura i Historia”, nr 18 (2010), http://biblioteka.teatrnn.pl/dlibra/Content/43596/Historia_mowiona_www.kulturaihistoria.umcs.lublin.pdf (dostęp: 14 II 2019 r.).

Kałwa D., ${ }_{3}$ R: Historia mówiona w polskich badaniach dziejów najnowszych, „Wrocławski Rocznik Historii Mówionej", R. 7 (2017), s. 163-183.

Kaźmierska K., Wywiad narracyjny - technika i pojęcia analityczne, [w:] Biografia a tożsamość narodowa, red. M. Czyżewski, A. Piotrowski, A. Rokuszewska-Pawełek, Łódź 1997, s. 35-44.

[Kersten K.] J. Bujnowski, W oczach komunistów. Stowo wstępne, [w:] T. Torańska, Oni, Londyn 1985 , S. 5-23.

Kersten K., Kłopoty ze świadkiem historii, [w:] T. Torańska, Oni, Warszawa 1990 (wyd. 2), s. 5-13.

Kowal P., Koniec systemu władzy, Warszawa 2012.

Kowal P., Koniec PZPR, „Polityka”, https://www.polityka.pl/tygodnikpolityka/historia/1606819, 2,koniec-pzpr.read (dostęp: 25 IV 2019 r.).

Kurkowska-Budzan M., Informator, świadek historii, narrator - kilka wątków epistemologicznych $i$ etycznych oral history, „Wrocławski Rocznik Historii Mówionej”, R. 1 (2011), s. 9-34.

Kwiatkowski T.P., Pamięć zbiorowa społeczeństwa polskiego w okresie transformacji, Warszawa 2008.

Maj E., Relacja $z$ wizyty ministra spraw zagranicznych Mariana Orzechowskiego w Teheranie (2-6 luty 1987), „Przegląd Orientalistyczny”, 2016, nr 1-2, s. 141-153.

Maruszewski T., Pamięć autobiograficzna, Gdańsk 2005.

McGrath C., Oral history and political elites. Interviewing (and transcribing) lobbyists, [w:] Oral History. The challenges of dialogue, red. M. Kurkowska-Budzan, K. Zamorski, Amsterdam-Philadelphia 2009, s. 47-60.

Modzelewski - Werblan. Polska Ludowa, oprac. R. Walenciak, Warszawa 2017.

Musiał F., Pierestrojka - droga do demokracji czy plan odwilzy bis?, „Biuletyn IPN”, nr 5-6 (2009), s. 70-83.

Paczkowski A., Dyplomacja polska czasów kryzysu, [w:] Historia dyplomacji polskiej. T. VI: 1944/1945-1989, red. W. Materski, W. Michowicz, Warszawa 2010, s. 821-863.

Rakowski M.F., Dzienniki polityczne 1984-1986, Warszawa 2005. 
Robotycki C., Pamięć o PRL - antropolog wobec doświadczenia przeszłości własnej kultury, „Konteksty. Polska Sztuka Ludowa”, t. 57 (2003), nr 3-4, s. 66-70.

Rostkowska K., Oni Teresy Torańskiej - między wywiadem a przesłuchaniem, „Studia Medioznawcze", t. 59 (2014), nr 4, s. 129-136.

Rudnicka M., Czy istnieje życiorys mówiony? O przenikaniu gatunków mówionych i pisanych - próba genologii na przykładzie analizy wypowiedzi autobiograficznych, „Wrocławski Rocznik Historii Mówionej", R. 7 (2017), s. 69-101.

Stolarz A., Historia mówiona w warsztacie historyka mentalności, „Pamięć i Sprawiedliwość”, nr 20 (2/2012), s. 103-114.

Szumski J., Rozliczenia z ekipa Gierka 1980-1984, Warszawa 2018.

Wawrzyniak J., History and Memory: The Social Frames of Contemporary Polish Historiography, "Acta Poloniae Historica", nr 103 (2011), s. 127-146.

Wojciechowski P., Dziedzictwo zamętu, [w:] Spór o PRL, Kraków 1996, s. 51-67.

Wrona P., Żywe źródło historyczne. Historia mówiona oczami historyka, [w:] Historia mówiona $w$ świetle nauk humanistycznych $i$ społecznych, red. S. Niebrzegowska-Bartmińska, J. Szadura, M. Szumiło, Lublin 2014, s. 241-268. 
Talking to a politician is not an easy task for a researcher who needs to be mindful of the fact that the witness to history is playing by a given set of rules. The analysis of a biographical and journalistic interview with Marian Orzechowski, a professor of history and Poland's foreign minister from 1985 to 1988 , allows us to outline the advantages and disadvantages and differences and similarities between the two methods of interviewing and to make note of the characteristic features of the relationships between politicians of the communist period, such as the schematics, the intellectual mishmash, and the narration of a story based on the semi-truths which is then interpreted and verified. This article addresses the question of understanding the mentality and identity of the politician as well as the factual value of interviews, assuming that all the spoken testimonies are psychologically true.

Keywords: biographical interview, journalistic interview, Marian Orzechowski, politicians in communist Poland
Ewa Maj

Methods of conducting a conversation with a politician of the PRL. Biographical and journalistic interview on the example of meetings with Marian Orzechowski 